\title{
Regional Development Poles and the Transformation of African Economies
}

This book argues that the development of capital goods manufacturing industries in four relatively large African economies will create regional development poles, from which industrialization will spread to the smaller African countries.

In this book, Benaiah Yongo-Bure explains the need for capital goods industries in Africa and shows how manufacturing can transform economies. He outlines the roles of the Democratic Republic of Congo (DRC), Ethiopia, Nigeria, and South Africa as potential regional development poles, showing how the existing economies, natural resources, and populations of these countries make them ideal candidates, while also considering possible challenges to industrialization. Finally, the author assesses what major infrastructural development is needed to link the countries and regions to increase the spread effects of economic growth.

This book will be of interest to scholars and policymakers in economic development and regional development in Africa.

Benaiah Yongo-Bure is Associate Professor of Economics at Kettering University, USA. 
Routledge contemporary Africa series

\section{Africa's Elite Football}

Structure, Politics, and Everyday Challenges

Chuka Onwumechili

Social Licensing and Mining in South Africa

Sethulego Matebesi

The Everyday Life of the Poor in Cameroon

The Role of Social Networks in Meeting Needs

Nathanael Ojong

Introduction to Rwandan Law

Jean-Marie Kamatali

State Fragility and Resilience in Sub-Saharan Africa

Indicators and Interventions

John Idriss Lahai and Isaac Koomson

Press Silence in Postcolonial Zimbabwe

News whiteouts, Journalism and Power

Zvenyika E. Mugari

Urban Planning in Rapidly Growing Cities

Developing Addis Ababa

Mintesnot G. Woldeamanuel

Regional Development Poles and the Transformation of African Economies

Benaiah Yongo-Bure

For more information about this series, please visit: www.routledge.com/ Routledge-Contemporary-Africa/book-series/RCAFR 


\section{Regional Development Poles and the Transformation of African Economies}

\section{Benaiah Yongo-Bure}

Kettering University Flint, MI, USA

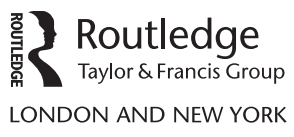


First published 2020

by Routledge

2 Park Square, Milton Park, Abingdon, Oxon OX14 4RN

and by Routledge

52 Vanderbilt Avenue, New York, NY 10017

Routledge is an imprint of the Taylor E Francis Group, an informa business

(C) 2020 Benaiah Yongo-Bure

The right of Benaiah Yongo-Bure to be identified as author of this work has been asserted by him in accordance with sections 77 and 78 of the Copyright, Designs and Patents Act 1988.

All rights reserved. No part of this book may be reprinted or reproduced or utilized in any form or by any electronic, mechanical, or other means, now known or hereafter invented, including photocopying and recording, or in any information storage or retrieval system, without permission in writing from the publishers.

Trademark notice: Product or corporate names may be trademarks or registered trademarks, and are used only for identification and explanation without intent to infringe.

British Library Cataloguing-in-Publication Data

A catalogue record for this book is available from the British Library

Library of Congress Cataloging-in-Publication Data

A catalog record has been requested for this book

ISBN: 978-0-367-44440-2 (hbk)

ISBN: 978-1-003-02480-4 (ebk)

Typeset in Bembo

by Apex CoVantage, LLC 


\section{Contents}

List of figures and tables vi

Preface and acknowledgment vii

Abbreviations $\quad$ ix

1 Capital goods and economic transformation 1

2 Manufacturing and the transformation of African economies 20

3 Theoretical perspectives $\quad 43$

4 The Congolese economy $\quad 62$

5 The Ethiopian economy 88

6 The Nigerian economy 118

7 The South African economy 144

8 Developing infrastructure networks $\quad 170$

9 Summary, conclusion, and policy implications 194

Appendices $\quad 207$

Index 215 


\section{Figures and tables}

\section{Figures}

3.1 Unbalanced growth-induced decision making 50

3.2 Critical minimum effort 53

3.3 Low-level equilibrium trap $\quad 55$

\section{Tables}

1.1 Industrialization and intra-African trade 5

1.2 Projections of Africa's population to 2050 (thousands) 8

1.3 Top 20 fastest-growing African cities 10

2.1 Structural changes in large African economies 23

2.2 Structural changes in exports of large African economies 24

2.3 Structural changes in imports of large African economies 26

2.4 Average annual sectoral growth of output of large African economies 28

2.5 Changes in demand structure of large African economies (percent of GDP) 33

4.1 Macroeconomic performance (percent in real terms) 64

4.2 The performance of the external sector (percent of GDP in real terms) 67

5.1 Macroeconomic performance (percent in real terms) 91

5.2 The performance of the external sector (percent of GDP in real terms) 98

6.1 Macroeconomic performance (percent in real terms) 120

6.2 The performance of the external sector (percent of GDP in real terms) 121

7.1 Macroeconomic performance (percent in real terms) 145

7.2 Structure of the economy, 2013

7.3 The performance of the external sector (percent of GDP in
real terms)

7.4 The structure of manufacturing in 2014 (percent) 154 


\section{Preface and acknowledgment}

The structures of virtually all African economies are not consistent with the patterns of consumption of the populations. Like people elsewhere in the world, Africans' demand is mostly for manufactured goods, most of which are imported from outside the continent. This situation is heightened with the sources of production inputs, especially of machinery and equipment. Most of the modern manufacturing carried out within Africa is concentrated on consumer goods, assembling from imported components, and processing of primary products. These subsectors of manufacturing are not technologically dynamic; have limited backward and forward linkages to the domestic economies; and are import- and foreign exchange-intensive. They cannot lead a country to self-sustaining development.

The manufacture of capital goods is the key to initiating a self-sustaining economy. Capital goods industries can supply the economy with a variety of productive inputs. They are technologically dynamic as technology is embodied in capital goods. Capital goods industries enable an economy to be flexible in adjusting to changing demand and production patterns.

Machinery and other capital goods are on what all African countries spend their inelastic foreign exchange. During times of depressed world market commodity prices, most African countries can hardly meet their requirements for imports, including imports of capital goods. Consequently, they cannot fulfil their development programs nor even carry out maintenance and repair of their existing productive capacities.

As technological progress takes place in the technologically advanced countries, African economies are forced to either replace their existing machinery or lag behind technologically. They may have to scrap still-useful productive capacities because of lack of spare parts or replacement inputs. Therefore, instead of increasing their capital stocks, such countries are tied to replacement of the same capital stock.

However, given the limited sizes of their domestic markets and resources not all African countries can manufacture large capital goods. Only a few African countries are large enough to sustain the manufacture of most capital goods. The few large African countries will have to undertake the establishment of heavy manufacturing machinery. The establishment of integrated infrastructure 
networks will facilitate cheaper diffusion of the capital goods among African countries.

\section{Acknowledgment}

This work is to a large extent a result of my teachers and colleagues in development economies during both my undergraduate and graduate studies. I have pondered over the years as I reflect on the role of development economics on African development. I also wish to thank the anonymous reviewers of the manuscript, especially the one who suggested to include the impact of the Belt and Road Initiative in the analysis. The staff of Routledge, especially Leanne Hinves, Henry Strang, and Aruna Rajendran, have done a professionally excellent job in preparing the book for publication. Thanks also go to my son, Jame, for taking over the running of the family errands while I prepared the manuscript for publication. 


\section{Abbreviations}

\begin{tabular}{|c|c|c|}
\hline AfDB & $=$ & African Development Bank \\
\hline AMU & $=$ & Arab Maghreb Union \\
\hline ASM & $=$ & Artisanal and Small Scale Mining \\
\hline AU & $=$ & African Union \\
\hline AUC & $=$ & African Union Commission \\
\hline BRI & $=$ & Belt and Road Initiative \\
\hline CAR & $=$ & Central African Republic \\
\hline CENSAD & $=$ & Community of Sahel-Saharan States \\
\hline COMESA & $=$ & Common Market for Eastern and Southern Africa \\
\hline CSR & $=$ & Corporate Social Responsibility \\
\hline DRC & $=$ & Democratic Republic of Congo \\
\hline EITI & $=$ & Extractive Industries Transparency Initiative \\
\hline ECA & $=$ & East African Community \\
\hline ECCAS & $=$ & Economic Community of Central African States \\
\hline ECOWAS & $=$ & Economic Community of West African States \\
\hline HEPC & $=$ & Heavily Indebted Poor Countries \\
\hline IGAD & $=$ & Intergovernmental Authority on Development \\
\hline NEPAD & $=$ & New Partnership for Africa's Development \\
\hline OAU & $=$ & Organization for African Unity \\
\hline OHADA & $=$ & $\begin{array}{l}\text { Organization for the Harmonization of Business } \\
\text { Law in Africa }\end{array}$ \\
\hline PIDA & $=$ & Program for Infrastructure Development in Africa \\
\hline PIDA-PAP & $=$ & PIDA Priority Action Plan \\
\hline SADC & $=$ & Southern African Development Community \\
\hline SNEL & $=$ & Societe Nationale d'Electricite \\
\hline UNECA & $=$ & United Nations Economic Commission for Africa \\
\hline UNEP & $=$ & United Nations Environmental Program \\
\hline
\end{tabular}




\section{Capital goods and economic transformation}

\section{Introduction}

Economic transformation requires the diversification and industrialization of an economy. The industrial sector includes a number of subsectors such as mining, manufacturing, construction, electricity, water, and gas. However, of all these, manufacturing is the most transformative subsector of industry. But not just any kind of manufacturing is sufficient to transform an economy. Distinction must be made among the three subsectors of manufacturing, namely manufacturing of consumer goods, intermediate goods, and capital goods.

Consumer goods industries produce goods that are ready for final use. These are the factories that process food, clothing, footwear, beverages, and the thousands of other ready-for final-use products. The machinery they use is produced by capital goods industries. Intermediate goods are inputs used in the manufacture of both consumer goods and capital goods. These include industries manufacturing bolts and joints, spare parts, industrial inputs, ingredients such as sugar used in the manufacture of confectionery, and many other inputs. The machinery for making all types of manufactures originates from the capital goods industries.

As can already be seen, capital goods are the manufactured goods that are used to produce all machinery, plus those used in machinery's own production. It is a diverse sector used to manufacture machinery and equipment used in various types of manufacturing. They include engineering and construction machineries, agricultural, transportation, energy generation, and equipment, and so many types of machinery and equipment for various sectors. They have profound impact on various sectors of the economy. They are also the subsector where most technological innovations take place.

The embodiment of technology in capital goods industries makes the subsector the most dynamic. Once a country establishes a substantial size of the capital goods subsector, it can supply many of its own industries with machinery and equipment, and it can guide much of its own technological advancement. Hence, the establishment of large capital goods manufacturing within Africa is crucial for African economic transformation. This is because Africa needs large-scale plants for the manufacture of strategic capital goods such as 
energy generation and transmission equipment, agricultural processing plants, chemical plants, transport machinery and equipment, mining machinery, and many other various manufacturing machinery and equipment.

Capital goods manufacturing is also characterized with economies of scale as many indivisibilities and high-skilled labor are involved in their construction and operation. Capital goods manufacturing is the most dynamic subsector. It supplies itself as well as the other two manufacturing subsectors with inputs. Capital goods industries are technologically dynamic; their regular supplies to all sectors of the economy ensure regular capacity utilization and technological flexibility in the whole economy. With flexible and rapidly changing technology, as consumer demand changes, the economy's capacity to adjust to the changing demand patterns will instantaneously adapt, ensuring fairly stable adjustments in the economy.

Metal processing and manufacturing is an important component of the capital goods industry. According to the International Standard for Industrial Classification, the metal industry consists of basic metal and engineering industry. The engineering industries can be further grouped into: manufacture of basic iron and steel; manufacture of fabricated metal products except machinery and equipment; manufacture of machinery and equipment; and manufacture of motor vehicles, trailers, and semi-trailers. ${ }^{1}$

\section{The engineering subsector}

Machinery and equipment needed in manufacturing are products of the engineering subsector.This subsector embodies most technologies in the machinery and equipment it makes and uses. It comprises elements such as engineering design and development, tool engineering and production, production engineering, materials engineering, and maintenance engineering. Together these subsectors translate science and technological innovations and developments into new, more efficient and more economical machines, plants, and equipment. The engineering industry has the capacity to design, adapt, and manufacture the components of new technical systems as well as repair, modify, and rehabilitate existing industrial plants and equipment.Therefore, the engineering industry, drawing from the basic metals and metal-working industries, constitutes the central pillar of an industrial economy (Agbu 2007). Hence, industrialization and technological development are not just a matter of importing more efficient equipment and installing it. It must be linked with fundamental development of scientific knowledge and capital goods industry and the capability to adapt them flexibly into an evolving economy. This process must be internalized within the domestic economy for dynamic and flexible economic transformation to take place.

In view of foreign exchange constraints for importing machine tools, the need to achieve a level of self-reliance in this strategic subsector through the local manufacture of machine tools is a precondition for self-sustaining development, not only of the engineering industry, but also of industry in general and the rest 
of the economy. Capability in the manufacture and use of machine tools would also contribute to the repair and maintenance of machinery and equipment used in various socio-economic activities. Machinery and equipment are what absorbs most of African foreign exchange as virtually all of them are imported far from outside the continent. Given the necessity of capital and intermediate goods in all industrial activities, shortage of foreign exchange means a predominantly importing economy comes to a halt. This was what happened to most African economies from the 1970s when the prices of petroleum and machinery rose considerably beyond the prices of African exports. This led to the International Monetary Fund's (IMF) structural adjustment programs, the debt crises, and the two lost decades of African development of the 1980s and 1990s.

Establishment of the capital goods subsector would make technological adaptation and innovation in Africa flexible. New technological capital goods and spare parts would be more easily acquired through acquisition of the currencies of the capital-goods-producing African countries in the neighborhood.

Foreign trade cannot be relied upon permanently for self-sustaining development or as an engine of growth and transformation. Foreign trade led to the establishment of the current structures of African economies. As foreign demand changes, the performances of African economies responded accordingly. African economies boomed as foreign demand for African primary products rose during the colonial period; and in the early post-colonial periods of the 1960s and early 1970s. The post-Second World War boom, due to reconstruction in the west and the boom of the 1960s, helped African economies boom temporarily. However, the prolonged difficulties in the world economy, from the 1970s, pushed the dependent African economies to the lost decades of the 1980s and 1990s.

Africa's positive economic performance in the 2000s relied mainly on the demand for African oil and minerals from China, India, and other newly industrializing economies. African economies withstood or recovered fast from the Great Recession of 2007-2009 because of the changes in the continent's direction of trade to China and India. However, as China's growth rate slowed, African oil and mineral exporters began to experience economic difficulties. Africa must use the enormous export earnings it brings in during foreign demand booms to transform its economies so that when the foreign demand declines, the continent is able to sustain its economies largely through internal African demand. The huge potential African market must be developed through integrated and transformed African economies.

The strategy of commodity-based industrialization of the United Nations Economic Commission for Africa and the African Union Commission (UNECA and AUC 2013a) is a necessary prelude and ingredient of the capital goods industrialization strategy (UNECA 2013b). Commodity industrialization will boost the African market and skills, and contribute to African integration as it will promote intra-industry trade. It will also promote rural development and expand the African market. Most of the intra-African trade is in manufactured goods rather than in raw agricultural products ${ }^{2}$ (Linder 1961). 
The consumption of many raw agricultural products is more culturally specific than that of manufactured products. Processed and manufactured agricultural exports will earn Africa more foreign exchange, which will help in capital goods industrialization. However, massive exportation of similar manufactured agricultural products to the world market may lead to worsening of African terms of trade as such massive increase in exports will flood the world market and depress commodity export prices.

As Table 1.1 shows, the more industrialized African countries have more intra-African exports than imports. These include Cote d'Ivoire, Kenya, and South Africa. South Africa, being the most industrialized African country, exports manufactured goods to virtually all African countries. Cote d'Ivoire and Kenya are among the relatively more industrialized African countries. They export substantial manufactures mostly to their neighbors. Hence, intra-African trade should generally increase as manufacturing and transformation progress in African economies.

Nigeria's higher exports and imports are explained by its export of petroleum to many African countries. South Africa's large value of intra-African imports results mainly from its imports of petroleum, particularly from Angola and Nigeria. Ethiopia's low value of intra-African trade can partly be explained by the classification of some of its major African markets, such as Djibouti and Somalia, as Middle Eastern markets. The high level of Cote d'Ivoire's intra-African imports reflect manufactures from South Africa and other fairly industrialized economies in West Africa such as Ghana and Senegal. Cote d'Ivoire also imports oil from Angola, Cameroon, Equatorial Guinea, Gabon, and Nigeria.

\section{Technology and development}

Technology is critical in economic transformation. Together with efficiency, technology improves the productivity of all factors of production, releasing resources for an ever-higher level of output. However, technology is not only the scientific and machine-tool knowledge, and tools and machines. It also encompasses the country-specific human understanding, skills, education, and training essential for making use of this knowledge, machines, and tools. Thus, technology is specific to each economy or similar economies. It has different effects on productivity in different economies or even firms since the tools are combined with labor forces in each economy with specific accumulated skills operating within a larger institutional and organizational framework.

The more rapidly technological knowledge can be adapted and put to work in an economy, the more rapid will be the pace of economic growth. This requires that workers and entrepreneurs have hands-on experience using such ideas in the act of producing. The more such machines and equipment are domestically produced, the more familiar the local workers are to their operations and adoptability to different industrial needs and uses.

Technology and human capital are fundamental complementary inputs affecting the rate of economic growth and the level of per capita income. 


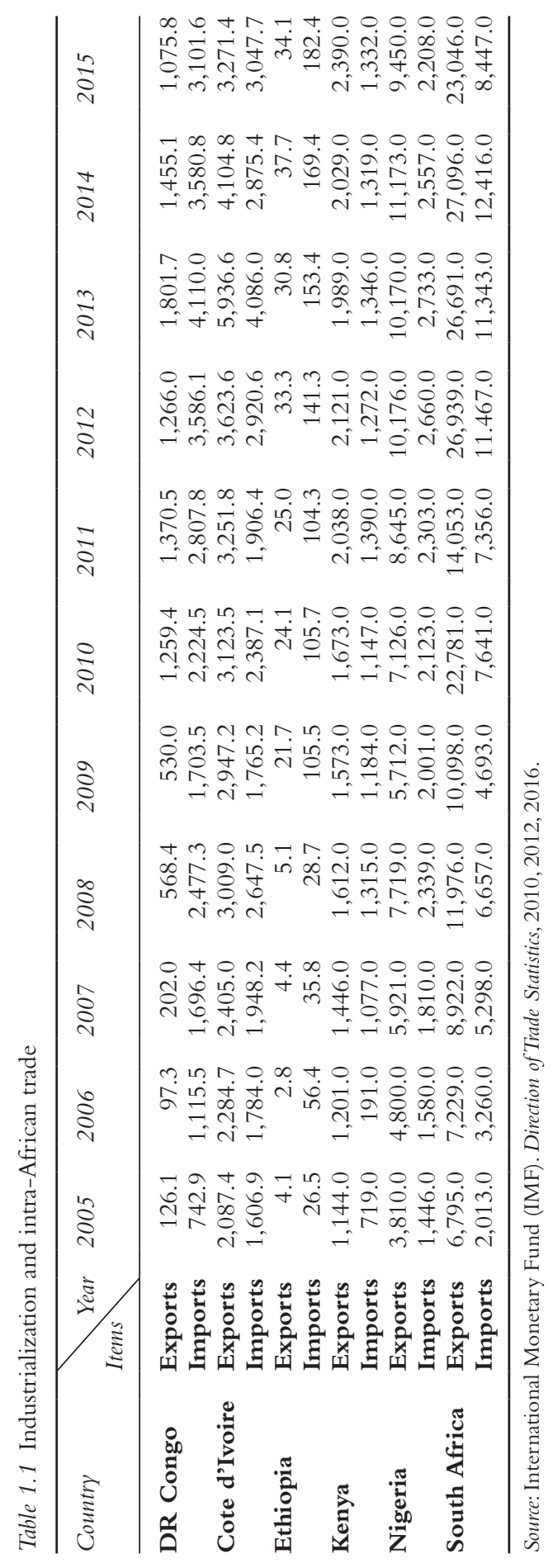


Technological knowledge in use is economy specific as a result of differences in the capacity of end-users to apply knowledge in the production process. There is need to focus on social investment in specific human capital and organizational inputs if such knowledge is to be utilized to its full effect. There are gaps among economies and each economy must develop its own relatively unique technological base. Investment in complementary inputs is very important, particularly in education and research and development $(\mathrm{R} \& \mathrm{D})$, which contribute over time to each country's specific capability to effectively make use of the world's supply of technological knowledge.

Without continuous technological change, economic growth slows and eventually development falters. Rapid economic growth and transformation cannot be achieved without continuous technological investment. The successful introduction of technology into the domestic production process in any country requires a domestic scientific establishment capable first of understanding, adopting, and adapting new, often foreign-created, technological knowledge to the specific needs of the domestic economy. Machines and tools often have to be customized to fit local conditions; that is, technology is "borrowed" from the world supply and made to fit the local economy. But borrowing cannot be in perpetuity. Efforts have to be made to indigenize the technology through domestic investment and innovation. This needs the building of substantial domestic economic capability. Neighboring countries, at approximately similar cultural levels of development, have more relevant experiences to share.

Virtually all the manufacturing industries set up in Africa at independence were consumer goods industries. They were capital-intensive, imported from the former colonial powers. This made their operations hinge on availability of foreign exchange; otherwise the plants would operate at very low capacity or even be closed down for want of foreign exchange to import spare parts, raw material, or replacement machinery and equipment. There is no dynamism in such industries. Hence, they cannot be the basis of transforming African economies.

\section{The sizes of African economies and markets}

The Appendix shows various indicators of the sizes, capacities, and indices of human development of virtually all African economies as of 2015, relative to the rest of the world. These indices include land areas, populations, national income and per capita incomes, infant mortality and life expectancy, and the development of education at various levels.

The small fragmented markets of most individual African economies cannot support the establishment of capital goods industries. Unless established on regional basis, such industries would be underutilized in most individual African countries. Moreover, in many cases, technology designed for developed countries are not suited for African countries at present stages of development.

While the initial capital goods can be imported from the established industrial countries, reliance on importation should not be continued indefinitely. 
Development of domestic capital goods industries must be established so that over time the national economy will largely depend on domestic capital goods industries so as to ensure sustainable supplies of machinery and equipment, spare parts, and other inputs to its various sectors. Capacity utilization and further growth of the economy may be frustrated by constraints in the importing capacity of the economy for foreign inputs. Such constraints may arise from shortage of foreign exchange. For example, inability of a country to import may arise from uncertainty in the international market for its exports, rendering a country unable to import vital inputs for its economy. This may lead the economy to operate much below its full capacity. Even old machinery and equipment may not be replaced, leading the economy to stagnate or operate very inefficiently.

But if the capital goods were domestically manufactured, or at least made in the neighborhood, their acquisition may be easier as the currencies of the neighboring countries are easier to obtain than those of the farther away countries with hard currencies. In the absence of domestic capital goods or capital goods in the neighborhood, domestic savings cannot be converted into capital goods unless it is changed to a hard currency. For example, the small neighboring countries of South Africa can easily acquire their industrial and mining inputs from South Africa by using the South African rand even if they do not have sufficient dollars, euros, or yen. However, this is not the case for most African countries.

Regional integration would provide African countries with the opportunity to pool their markets and resources. By establishing these industries in Africa, technological progress will be internalized in Africa; in the long-run, this will introduce flexibility into African industry as technological progress will be internally generated and machinery and equipment designs will keep pace with the required changes in manufacturing as the structure of demand changes with development.

However, there are a few large African countries with large resources and potential domestic markets that can go a long way in establishing large manufacturing sectors from which industrialization can diffuse to the neighboring countries. Given the slower rate of regional integration in Africa, the few large single African political entities could be developed into major regional development poles from which industrialization can more easily diffuse to the rest of the continent.

Table 1.2 shows that there were seven African countries in 2015 that had populations of approximately 50 million and above. By 2030 and 2050, this number of countries will increase to ten and twenty-two respectively. However, these countries have different resource endowments. Some are arid, while others will soon be densely populated. Hence, they offer different potentials for individual self-sustaining industrialization. By 2050, Nigeria is projected to have the world's fourth-largest population.

From the projected world population on Table 1.2, many African countries will have over forty million people each by 2050 , which constitute a sizable domestic market. Educated and trained, such numbers of young people would 
Table 1.2 Projections of Africa's population to 2050 (thousands)

\begin{tabular}{rlrrr}
\hline No & Country & \multicolumn{1}{l}{2015} & \multicolumn{1}{c}{2030} & \multicolumn{1}{c}{2050} \\
\hline $\mathbf{0}$ & World & $\mathbf{7 , 3 4 9 , 4 7 2}$ & $\mathbf{8 , 5 0 0 , 9 6 6}$ & $\mathbf{9 , 7 2 5 , 1 4 8}$ \\
$\mathbf{0 0}$ & Africa & $\mathbf{1 , 1 8 6 , 0 0 0}$ & $\mathbf{1 , 6 7 9 , 0 0 0}$ & $\mathbf{2 , 4 7 8 , 0 0 0}$ \\
1 & Algeria & 39,667 & 48,274 & 56,461 \\
2 & Angola & 25,022 & 39,351 & 65,473 \\
3 & Burkina Faso & 18,106 & 27,244 & 42,789 \\
4 & Cameroon & 23,344 & 32,947 & 48,362 \\
5 & Côte d'Ivoire & 22,702 & 32,143 & 48,797 \\
6 & Dem. Rep. of Congo & $\mathbf{7 7 , 2 6 7}$ & $\mathbf{1 2 0 , 3 0 4}$ & $\mathbf{1 9 5 , 2 7 7}$ \\
7 & Egypt & $\mathbf{9 1 , 5 0 8}$ & $\mathbf{1 1 7 , 1 0 2}$ & $\mathbf{1 5 1 , 1 1 1}$ \\
8 & Ethiopia & $\mathbf{9 9 , 3 9 1}$ & $\mathbf{1 3 8 , 2 9 7}$ & $\mathbf{1 8 8 , 4 5 5}$ \\
9 & Ghana & 27,410 & 36,865 & 50,071 \\
10 & Kenya & $\mathbf{4 6 , 0 5 0}$ & $\mathbf{6 5 , 4 1 2}$ & $\mathbf{9 5 , 5 0 5}$ \\
11 & Madagascar & 24,235 & 35,960 & 55,294 \\
12 & Malawi & 17,215 & 26,584 & 42,155 \\
13 & Mali & 17,600 & 27,370 & 45,404 \\
14 & Morocco & 34,378 & 39,787 & 43,696 \\
15 & Mozambique & 27,978 & 41,437 & 65,544 \\
16 & Niger & 19,899 & 35,966 & 72,238 \\
17 & Nigeria & $\mathbf{1 8 2 , 2 0 2}$ & $\mathbf{2 6 2 , 5 9 9}$ & $\mathbf{3 9 8 , 5 0 8}$ \\
18 & South Africa & $\mathbf{5 4 , 4 9 0}$ & 60,034 & 65,540 \\
19 & Sudan & 40,235 & 56,443 & 80,284 \\
20 & Tanzania & $\mathbf{5 3 , 4 7 0}$ & $\mathbf{8 2 , 9 2 7}$ & $\mathbf{1 3 7 , 1 3 6}$ \\
21 & Uganda & 39,032 & 61,929 & $\mathbf{1 0 1 , 8 7 3}$ \\
22 & Zambia & 16,212 & 25,313 & 42,975 \\
\hline
\end{tabular}

Source: United Nations, Department of Economic and Social Affairs, Population Division. 2015. World Population Prospects: The 2015 Revision. New York, NY: United Nations.

constitute a large labor force. With equitable national development that widens their individual national markets, the countries with large natural resources could pursue viable industrialization programs, with substantial establishment of capital goods industries. While all African countries can pursue the strategy of commodity-based industrialization for raising general living conditions for the majority of the African population, manufacture of capital goods in Africa is a prerequisite for establishing self-sustained development in the continent. The commoditybased industrialization will raise the general living conditions of the populations, greatly reducing unemployment and underemployment, poverty, and inequalities as well as expanding the national markets for further industrialization. But they will need continuous importation of capital goods from afar, outside Africa. Availability of foreign exchange has always been a major impediment, limiting African imports from outside the continent.

\section{Population dynamics and economic transformation}

Africa is a youthful continent and the demographics of adolescents and youth will largely shape the future social and economic development prospects of the 
continent. Africa's share of the world population will increase from 13 percent in 2012 to 24 percent in 2050. Africa's median age was 19.7 in 2012 and will increase to 25.4 in 2050. This is in contrast to median age of 30.4 for the world, which is projected to reach 37.9 in 2050 (Janneh 2012).

Approximately 85 percent of all the people in Africa in 2012 were below age 45 while only 5 percent of them were aged 60 or more. As these ratios are not expected to change much by 2050, Africa will continue to be youthful for the foreseeable future. Young people below age 30 will increase from about 729 million in 2012 to 1.2 billion in 2050 . Within the same period, adolescents aged 10 to 19 will increase from 237 million to 416 million, and youth aged 15 to 24 will increase from about 212 million to 391 million (Janneh 2012).

These people need to be provided for so that they will be productive and contribute positively to society. If left to grow in poverty, the situation will only get worse. Investment in food, housing, health, and education are a must for a brighter future. These investments will make the future more productive. Although youth literacy has increased, and gender disparities in education attainment have narrowed, many countries still have very low enrollment of less than 5 percent in tertiary education. There is need to extend progress made in achieving universal primary education to secondary and tertiary levels. Besides improving the knowledge and skills levels, investment in secondary and tertiary education will promote the contribution of youth and adolescents to productivity and competitiveness of the African economies.

Youth in Africa face the challenge of high unemployment and poverty, and low productive jobs mainly in the informal sector. Many African youth perish in the Sahara Desert and the Mediterranean Sea while trying to travel in search of job opportunities in Europe. This unfortunate situation will continue to be perpetuated unless major transformational development policies are initiated within Africa. Therefore, there is an urgent need for addressing youth unemployment in Africa. Economic diversification and transformation will create employment opportunities for the African youth entering the labor market every year.

Economic growth and development will also simultaneously address the problems of poverty and inequality and create stability in societies. Significant investment in health, education, and employment will enable African countries to reap high economic returns from the large and rapidly increasing number of youth and adolescents. They will supply the labor market and constitute the rising market of African middle class.

With lack of opportunities in the rural areas, most youth are pushed to the urban areas. The urban areas are where open unemployment and glaring inequalities are much more dangerous to individual and national security. Hence, urbanization is one of the most significant population trends and problems in Africa. And as education expands, the rate of rural-urban migration will accelerate. Without dynamic industrial economies, economic, social, and political problems will intensify in the continent. To reap any demographic dividend, Africa must first massively invest in its youth. 
Urban population growth is increasing rapidly in virtually all African countries, driven both by natural increase in urban areas and widespread rural-urban migration. The process of urbanization can provide countries with enormous opportunities to achieve sustainable development, including economic growth, poverty reduction, and service provision via agglomeration economies of scale. At the same time, rapid urbanization can bring with it significant challenges depending on government capacity, planning, and response, such as slum growth, inadequate provision of services and infrastructure, poor health and quality of life, and environmental degradation. In Africa, at present, the negative aspects of urbanization by far outweigh the positives. This trend needs urgent reversal through economic transformation.

Although Africa is the least urbanized continent, its rate of urbanization is the fastest in the world. Urban inhabitants grew from 33 million persons in 1950 to 414 million in 2011, 471 million by 2015, and are expected to reach 744 million by the year 2030, that is 47.7 percent of the population (UNECA and AUC 2013b).

Rapid urbanization implies that the urban settlements will progressively absorb the population growth in Africa. The continent will therefore witness an increase in population concentration in urban areas. An industrial economy absorbs more population than a more predominantly primary producing economy.

Table 1.3 Top 20 fastest-growing African cities

\begin{tabular}{rllrr}
\hline No & \multirow{2}{*}{ City } & Country & \multicolumn{2}{c}{ Population (Thousands) } \\
\cline { 3 - 4 } & & & 2010 & 2025 \\
\hline 1 & & Nigeria & 10,578 & 15,810 \\
2 & Lagos & D. R. Congo & 8,754 & 15,041 \\
3 & Kinshasa & Egypt & 11,001 & 13,531 \\
4 & Cairo & Angola & 4,772 & 8,077 \\
5 & Luanda & Cote d'Ivoire & 4,125 & 6,321 \\
6 & Abidjan & Kenya & 3,523 & 6,246 \\
7 & Nairobi & Tanzania & 3,349 & 6,202 \\
8 & Dar es Salaam & Egypt & 4,387 & 5,648 \\
9 & Klexandria & Nigeria & 3,395 & 5,060 \\
10 & Addis Ababa & Ethiopia & 2,930 & 4,757 \\
11 & Dakar & Senegal & 2,863 & 4,338 \\
12 & Ibadan & Nigeria & 2,837 & 4,237 \\
13 & Johannesburg & South Africa & 3,670 & 4,127 \\
14 & Casablanca & Morocco & 3,284 & 4,065 \\
15 & Cape Town & South Africa & 3,405 & 3,824 \\
16 & Ekurhuleni & South Africa & 3,202 & 3,614 \\
17 & Algiers & Algeria & 2,800 & 3,595 \\
18 & Accra & Ghana & 2,342 & 3,497 \\
19 & Durban & South Africa & 2,879 & 3,241 \\
20 & Douala & Cameroon & 2,125 & 3,131 \\
\hline
\end{tabular}

Source: African Development Bank. Tracking Africa's Progress in Figures, 2014. 
At present, rapid urbanization entails high levels of urban poverty. Most studies reveal that between 15 and 65 percent of African city dwellers are living in poverty, very often in informal settlements with limited access to infrastructure, poor health and environmental conditions, and few social or urban services (UNECA and AUC 2013b). While cities continue to attract significant numbers of rural-to-urban migrants, primarily for economic opportunities, indicators for the urban poor in Africa are often the same or potentially worse than their rural counterparts. Inadequate infrastructure and high crime rates threaten poorer parts of cities. Well-informed and sound policies are needed to meet the demands of the growing numbers of urban poor, particularly to secure for them the benefits of urban living. A booming manufacturing economy would considerably overcome these challenges. It would substantially contribute to the reduction of unemployment, poverty, and inequalities.

Rural development and encouragement of growth of medium-sized cities in the regions would decongest the single large cities, usually the capital city of each country. These programs will be possible with a dynamic self-sustaining industrial economy coupled with a deliberate public policy to promote development in the national regions instead of leaving the backwash effects of the colonial pattern of development to dominate national economic policy.

\section{African industrialization strategies since independence}

Conscious industrialization policy in Africa, as in most other underdeveloped countries, began in the post-World War II period. Since the developed countries were industrialized, while the underdeveloped countries were primary producers, economic development came to be identified with industrialization. While prices of industrial exports persistently increased relative to those of primary products, prices of exported primary products were unstable and tended to decline or at best stagnate over time (Prebisch 1950; Singer 1950). As markets for primary products stagnated, and as synthetics were increasingly substituted for primary products, underdeveloped countries turned to industrialization as a strategy for economic growth and development.

Having decided to industrialize, the underdeveloped countries planned to substitute their industrial imports with local production. This was the strategy of import substitution industrialization. It was thought that underdeveloped economies would progress from the simpler level of manufacturing consumer goods to intermediate goods and eventually to the manufacture of capital goods.

Import substitution was expected to improve the balance of payments of underdeveloped countries as more manufactured imports would be produced domestically. Tariffs were imposed to protect the infant industries from foreign competition. But these tariffs became progressively higher with higher stages of processing. Foreign firms were encouraged to establish "tariff factories" to circumvent the protective tariffs. Their use of capital-intensive technologies resulted in limited employment opportunities. Frustrations with foreign firms 
led to their nationalization and/or the establishment of national public development corporations. However, neither proved viable in most underdeveloped countries.

The capital-intensive consumer industries themselves required more imports of spare parts, raw materials, and replacement capital goods, thus requiring more foreign exchange to service them. Consequently, more resources were being devoted to these urban industries than to the agricultural sector and rural development. Moreover, rural development was just understood in a narrow sense as just being agricultural development. Rural-urban migration increased, but because the capital-intensive industries created few jobs, open urban unemployment increased. While the urban unemployment did not generate much instability because the migrants were gullible peasants who largely blamed themselves for their misfortune, this is no longer the attitude of many of the urban poor as they have increasingly come to consist of school-leavers. Soon the majority of the urban poor will come to consist of university graduates who will not fear to directly challenge those wielding political and military power. The dire economic situation will lead to more serious social and political problems and confrontations between the authorities and unemployed who will increasingly come to consist of the politically conscious educated. With increases in university enrollments and output, the numbers and sophistication of the politically conscious unemployed is greatly increasing. Only expanding opportunities through viable self-sustaining economic development will greatly minimize socio-political instability.

Because of the limitations of import-substitution industrialization, underdeveloped countries changed their industrialization strategy to manufacturing for export. The export-of-manufactures strategy was recommended particularly for small economies with limited domestic markets. At the early stages of manufacturing, most underdeveloped countries produced similar products and could not absorb much of each other's products. Tariffs in the more industrially developed economies progressively increased with the degree of value added of manufactured imports from the underdeveloped economies unless an underdeveloped country was a satellite of a major industrial country ${ }^{3}$ (Todaro and Smith 2015: 588-614; Krugman and Obstfeld 2006: 243-258).

Given the barriers to export of manufactures, underdeveloped countries intensified efforts on promoting regional integration so as to pool their markets. But while the cooperating and integrating countries could see the joint benefits of integration, they could not easily agree on equitable sharing of these potential benefits. The partner states were at different low levels of industrialization, and each partner wanted to accelerate its own rate of industrialization and development. Hence, agreements on the location of industries among members of an integrating group became almost impossible. This outlook toward economic integration has not changed much, and hence the slow pace of regional integration in Africa. 


\section{Regional and continental integration}

The economic problems of the 1970s and 1980s led African countries to revert to the economic policies of market fundamentalism being expounded by conventional free market institutions such as the International Monetary Fund (IMF). But these were the bases of the colonial economic policies that had left Africa in the dependent economic position it was in at independence. Hence, there is no wonder that since the implementation of structural adjustment policies in Africa, poverty on the continent became more widespread and deepened. As dissatisfactions with the IMF structural adjustments became widespread, African countries renewed their determination for regional and continental integration with greater vigor. There was realization that African integration is a strategy for African development. It is intended not to follow development but to precede it; or both integration and industrialization must be pursued simultaneously. The argument that each country should solve its problems before entering into integration is spurious because lack of capacity is an integral part of the failure to develop. If each country could achieve its development on its own, then why integrate?

The intensification of efforts towards regional integration resulted in the adoption of the Lagos Plan of Action by the African Heads of State and Government in 1980. This step culminated in the signing of the Abuja Treaty of 1991 promulgating the African Economic Community (AEC), which came into effect in 1994. The agreement to establish the AEC Free Trade Area was signed in Kigali in March 2018. However, the full establishment of the AEC is to be phased out in six stages ${ }^{4}$ (Yongo-Bure 2011). The establishment of a continent-wide common market, the African Common Market (ACM), is aimed at realization by 2023 . The continent-wide economic and monetary union is to be achieved by the end of 2028. The transitional period, during which all these structures are to be established, would end by 2034 at the latest.

But as much as African leaders seem to appreciate the importance of collective African self-reliance, their political rhetoric on African integration has so far not been accompanied by commensurate results. Consequently, multiple regional groupings have been established all over the continent, many of which have overlapping memberships. This duplication and overlapping of membership in the regional integration blocs in Africa has hampered the progress of regional integration instead of facilitating it, thereby perpetuating Africa's vulnerability to global economic forces. ${ }^{5}$

Many countries have joined a number of groupings for political and strategic reasons. Economic reasons rank low. Duplication of membership hinders integration programs related to trade facilitation and market integration. Lack of harmonized market integration schemes means that each regional economic community has its own rules of origin or its own certification process. This limits trade between communities. The duplication and overlapping of membership contribute to the underfunding of the communities as members find it difficult to pay all their dues to multiple communities. There is also the problem 
of adequately staffing the many RECs with their various levels of technical needs. Declarations by the African Summit of July 2007 indicated a strong desire to rationalize the existing RECs and reflect a decision not to recognize more RECs than the eight then existing as the main pillars of the AEC (UNECA, Vol. 3: 30).

The acceleration of African regional and continental integration since the signing of the Abuja Treaty is a clear manifestation of African leaders' recognition of the need for larger economic units in the continent to achieve viable development in the current global economic environment. However, the processes of realizing the RECs and the AEC will be slow and long. In the meanwhile, technological changes will not wait for African integration. Such a situation will perpetuate Africa's follower status in regard to the challenges of

globalization. For Africans to have an impact and influence on the direction of globalization, and thus on the continent's destiny, African countries must internalize the processes of technological progress within a shorter time frame. The greater challenge of internalizing substantial technological changes within Africa can be undertaken by the large African countries that should be able to muster the political leadership to turn their potentials into regional development poles in the continent. Development emanating from these regional poles (or "African industrial workshops") will diffuse faster to the rest of the continent, thus enabling the smaller economies to transform faster than when depending on economic diffusion from outside the continent.

\section{The Regional Development Poles Strategy}

The strategy of Regional Development Poles (RDPs) places emphasis on accelerating the economic transformation of the few large African countries that can largely industrialize on their own efforts, based on their tremendous natural and human resources, and large domestic markets (Yongo-Bure 2014). The creation of "regional development poles" within Africa could lead to the establishment of diversified industrial economies on the continent, which may in turn lead to faster diffusion of economic development to the surrounding African countries. The building of intra-African highways, railways, long-distance power transmission lines, ports, and direct communications links could accelerate this diffusion, making it cheaper and faster for the rest of the smaller African countries to import development inputs from the neighboring development poles. The need to earn foreign exchange from the established hard currencies will be less desperate than at present, as it will become relatively easier to acquire the currencies of the neighboring development poles and import from them. And as African economies become increasingly more industrialized, diversified, and integrated, and intra-industry trade becomes significant, even smaller economies will be able to establish capital goods industries.

The strategy of regional development poles draws lessons from the strategies of big push or balanced growth and unbalanced growth of the 1960s. 
It advocates large investment in capital goods industries on the premises that lack of capital goods industries or inability to import them because of bottlenecks with foreign exchanges frustrates development efforts of most African countries. The structures of African industry have been unbalanced with bias towards the manufacture of consumer goods. This imbalance in industry has to be urgently addressed. But since most African countries are so small such that all cannot establish such large industries characterized with indivisibilities, the few large African economies with huge natural and financial resources as well as large potential domestic markets should undertake such manufactures. Combined with intra-African transportation networks, the few large African capital goods manufacturing countries will act as African Industrial Workshops. The cost of supplying capital goods to most African countries from within Africa will be less than the importation of capital goods from outside the continent. Moreover, both formal and informal importation from neighboring countries is possible given ease of contacts and acquisition of foreign currencies of neighboring countries. For example, South Africa's neighbors can easily acquire the rand and import from South Africa.

While the arguments against Rosenstein-Rodan's big push (1943) and Nurkse's balanced growth (1953) were based on the subsistence stages of the economies at their earlier stages of development, this is no longer the case with many African economies (Chapter 3). Moreover, African countries have reactivated the development of intra-African infrastructure as reflected in regional infrastructure development programs and the Program of Infrastructure Development in Africa (PIDA, Chapter 8). What will be taking place will be replacement of some capital goods from outside Africa with African manufactures. Hence, the African demand is available. Supply is feasible as many African countries such as Nigeria have been generating large investable resources from oil since the 1960s. Since the beginning of the twenty-first century, Ethiopia has been generating huge resources and investing in massive energy generating programs. The Democratic Republic of Congo has all the resources a country needs for a massive industrial development. What is lacking is a developmental political leadership.

While Hirschman (1958) believed that the preferable unbalanced path is the one led by investment in directly productive activities (DPAs) so that social infrastructure responds to pressure created by excess capacity of DPAs, many African countries and the African Union Commission are investing in infrastructure. Moreover, most African countries have already substantial amounts of human capital and can quickly train more from the many university and secondary school graduates. However, it is important to encourage DPAs along the infrastructure networks. Presence of infrastructure does not mean that DPAs will spontaneously sprout along the network. Action has to be taken to encourage productive activities along the infrastructure networks. Hence, the regional development poles strategy will mainly focus on creating the capital goods industries, although in many cases it will have to create some infrastructure, especially in the field of energy development. 
What the regional development poles strategy really advances is a new import substitution strategy focusing on manufacture of capital goods rather than the earlier strategy that concentrated on manufacture of consumer goods. Capital goods manufacturing has more impactful backward and forward linkages than the manufacture of consumer goods. Moreover, the supply and demand constraints African countries experienced at independence have been substantially reduced. Experience has been gained and lessons can be learned from similar recently underdeveloped but now industrializing economies such as Brazil and South Korea.

\section{Concluding remarks}

To fundamentally transform an economy, a country needs to establish an appropriate industrial infrastructure, develop research and development (R\&D) capability, and internalize technology. A dynamic industrial economy usually comprises numerous strategic industries such as basic metals, chemicals, metal working, and engineering. The basic metals include iron and steel and nonferrous metals such as aluminum, copper, tin, zinc, lead, and nickel. It involves mining, metallurgy, rolling, extrusion, and drawing that produce intermediate goods. These goods serve as inputs into the metal-working industry and constitute the basic capital goods industries, essential for self-sustaining economic growth and transformation.

Capital goods industries are usually large and depend on the exploitation of economies of scale. They have beneficial external effects in the surrounding countries as they have large-spread effects in the neighborhood. In light of the slow processes of regional integration, the small African economies will benefit from the establishment of such industries in the large African countries. The African Union, the New Partnership for African Development (NEPAD), the United Nations Economic Commission for Africa, and the African Development Bank, among other African organizations, together with the elites of the large African countries, should lead in the establishment of the viable development poles in the continent. Self-sustaining development of the rest of the countries on the continent will spread from the regional development poles. The establishment of diversified industrial economies, financial systems, and convertible currencies in the regional development poles will further facilitate industrialization in the smaller neighboring economies.

Regional integration is a slow process and cannot be the sole reliance on African economic transformation. The present regional groupings are riddled with duplication and overlapping membership, which results in a scattering of resources and efforts. Politicians make fine speeches on the need for African collective self-reliance, but they are loath to concede any of their vaunted sovereignty to a supranational body. Thus, while African countries should continue efforts toward achieving collective action to support development, those that are large enough to go it alone should spearhead a process to speed up transformation from their own economies. The regional development poles 
strategy will reinforce regional integration through greatly increased intra-industry African trade.

To maximize the spread effects of such a strategy, there is need to build intraAfrican infrastructure, especially transport networks, ports, energy, and ICT. The state will also have to play a crucial role in this process as has been the case throughout histories of national economic transformations. A developmental state endowed with tremendous natural and human resources can succeed more easily and faster than one lacking in both factors. Cooperation and collaboration with neighbors can help, but effective coordination of development policy by different political entities can be difficult and very slow, clouded with uncertainties, especially where legalistic sovereignty is overemphasized.

\section{Notes}

1 United Nations Department of Economic and Social Affairs. 2008. International Standard Industrial Classification of All Economic Activities Revision 4. New York, NY: United Nations.

2 Linder's hypothesis is that countries begin to export manufactures to markets with similar demand patterns.

3 While import duties in industrial countries for manufactures from developing countries increase with the degree of processing, export of Western corporations located in their satellite in the underdeveloped countries had free access to Western markets. Western ships and cargo planes returning from delivering military supplies to Far East countries also needed return cargo; this need necessitated transportation of Far Eastern manufactured products to the West duty free.

4 For details on the phases of realizing the African Economic Community, see Yongo-Bure 2011, 69-87.

5 The African Union has recognized only eight regional economic communities (RECs) as the bases of the African Economic Community. These are the Economic Community of West African States (ECOWAS), the Economic Community of Central African States (ECCAS), the Southern African Development Community (SADC), the East African Community (EAC), the Common Market for Eastern and Southern Africa (COMESA), the Inter-Governmental Authority on Development (IGAD), the Arab Maghreb Union (UMA), and the Community of Sahel-Saharan States (CENSAD).

\section{Bibliography}

Agbu, Osita. 2007. The Iron and Steel Industry and Nigeria's Industrialization: Exploring Cooperation with Japan Institute of Developing Economies. Osaka: Japan External Trade Organization.

Alemayehu, Makonnen. 2000. Industrializing Africa: Development Options and Challenges for 21st Century. Trenton and Asmara: Africa World Press, Inc.

Balassa, Bela. 1989. "Outward Orientation.” In Handbook of Development Economics, Vol. 2, eds. Hollis Chenery and T. N. Srinivasan. Amsterdam: North Holland Publishers: 1645-89.

Burton, Harry. 1989. "Import Substitution." In Handbook of Development Economics, Vol. 2, eds. Hollis Chenery and T. N. Srinivasan. Amsterdam: North Holland Publishers: 1601-44.

Chenery, Hollis. 1979. Structural Change and Development Policy. New York, NY: Oxford University Press.

Chenery, Hollis and Moshe Syrquin. 1975. Patterns of Development 1950-1970. Oxford: Oxford University Press. 
Cornwall, John. 1977. Modern Capitalism: Its Growth and Transformation. London: Martin Robertson.

Cypher, James M. and James L. Dietz. 2009. The Process of Economic Development. New York, NY: Routledge; Taylor \& Francis Group.

Hirschman, Albert A. 1958. Strategy of Economic Development. New Haven, CT:Yale University Press.

Janneh, Abdoulie. 2012. A Statement on Demographics of Adolescents and Youth in Africa. Addis Ababa: UNECA.

Krugman, Paul R. and Maurice Obstfeld. 2006. International Trade: Theory and Policy. New York, NY: Pearson Addison Wesley.

Lewis, Arthur W. 1954. "Economic Development With Unlimited Supplies of Labor." Manchester School of Economics and Social Studies 22: 139-91.

Lewis, Stephen R. Jr. 1989. "Primary Exporting Countries." In Handbook of Development Economics, Vol. 2, eds. Hollis Chenery and T. N. Srinivasan. Amsterdam: North Holland Publishers: 1542-600.

Linder, Staffan B. 1961. An Essay on Trade and Transformation. New York, NY: John Wiley \& Sons.

Myrdal, Gunnar. 1957. Economic Theory and Underdeveloped Regions. London: Duckworth.

Nurkse, Ragnar. 1953. Problems of Capital Formation in Underdeveloped Countries. New York, NY: Oxford University Press.

Prebisch, Raul. 1950. The Economic Development of Latin America and Its Principal Problems. New York, NY: United Nations.

Rosenstein-Rodan, Paul N. 1943. "Problems of Industrialization of Eastern and SouthEastern Europe.” Economic Journal 53, no. 2 (June-September): 202-11.

Singer, Hans. 1950. "The Distribution of Gains between Investing and Borrowing Countries." American Economic Review 40: 473-85.

Todaro, Michael P. and Stephen C. Smith. 2015. Economic Development. New York, NY: Pearson Addison Wesley.

United Nations Economic Commission for Africa (UNECA). 2015. Economic Report of Africa 2015: Industrializing Through Trade. Addis Ababa: UNECA.

-2014. Frontier Markets in Africa: Misperceptions in a Sea of Opportunities. Addis Ababa: UNECA.

United Nations Economic Commission for Africa (UNECA) and African Union Commission (AUC). 2013a. Making the Most of Africa's Commodities: Industrializing for Growth, Jobs and Economic Transformation. Addis Ababa: UNECA.

- 2013b. Policy Brief No 3: Urbanization and Development Transformation in Africa. Addis Ababa: UNECA.

-2011a. Economic Report on Africa 2011: Governing Development in Africa: The Role of the State in Economic Transformation. Addis Ababa: UNECA.

- 2011b. Africa Youth Report 2011:Addressing the Youth Education and Employment Nexus in the New Global Economy. Addis Ababa: UNECA.

-2011c. Policy Brief No 6: Unleashing Africa's Potential as a Pole of Global Growth. Addis Ababa: UNECA.

. 2011d. Minerals and Africa's Development: The International Study Group Report on Africa's Mineral Regimes. Addis Ababa: UNECA.

United Nations Economic Commission for Africa (UNECA), African Union Commission (AUC), and African Development Bank (AfDB). 2017. Assessing Regional Integration in Africa VIII: Bringing the Continental Free Trade Area About. Addis Ababa: UNECA. 
2016. Assessing Regional Integration in Africa Vol. VII: Assessing Regional Integration in Africa VII: Innovation, Competitiveness and Regional Integration. Addis Ababa: UECA.

2015. Africa Region Report on the Sustainable Development Goals: Summary. Addis Ababa: UNECA.

. 2013. Assessing Regional Integration in Africa Vol. VI: Assessing Regional Integration in Africa (ARIA VI): Harmonizing Policies to Transform the Trading Environment. Addis Ababa: UNECA.

- 2012. Assessing Regional Integration in Africa Vol. V: Assessing Regional Integration in Africa (ARIA V): Towards an African Continental Free Trade. Addis Ababa: UNECA.

- 2010. Assessing Regional Integration in Africa Vol. IV: Assessing Regional Integration in Africa IV: Enhancing Intra-African Trade. Addis Ababa: UNECA.

. 2008. Assessing Regional Integration in Africa Vol. III: Towards Monetary and Financial Integration in Africa. Addis Ababa: UNECA.

- 2006. Assessing Regional Integration in Africa Vol. II: Rationalizing Regional Economic Communities. Addis Ababa: UNECA.

-2004. Assessing Regional Integration in Africa Vol. 1: Policy Research Report. Addis Ababa: UNECA.

United Nations, Department of Economic and Social Affairs, Population Division. 2015. World Population Prospects: The 2015 Revision. New York, NY: United Nations.

Woldemichael, Andinet, Adeleke Salami, Adamon Mukasa, Anthony Simpasa, and Abebe Shimeles. 2017. Transforming Africa's Agriculture Through Agro-Industrialization. Abidjan: AfDB.

World Bank. Various years. World Development Indicators. Washington, DC: World Bank.

Yongo-Bure, Benaiah. 2014. "Regional Development Poles and Self-Sustaining Development in Africa." In Regional Economic Communities, eds. Olanrewaju A. Olutayo and Adebusuyi I. Adeniran. Dakar:The Council for the Development of Social Science Research in Africa (CODESRIA): 23-36.

—. 2011. "A Two-Track Strategy for Viable Development in Africa." In Rethinking Economic Development in the Context of Globalization and Sustainable Development in Africa, eds. Bessie House-Soremekun and Toyin Falola. Rochester, NY: University of Rochester Press: 69-87. 


\section{References}

1 A large geographical area contains many and diverse resources and can support the production of a large range of products. Large populations and high national incomes constitute large markets that can absorb large quantities and range of national products due to economies of scale.

2 A number of factors were taken into consideration in selecting the fifteen African countries being used as samples in this analysis. They must be contiguous (or easily linked) to most other African countries so that growth in them can more readily diffuse to the other countries. Countries in the Sahara and Sahel were excluded given the relative difficulty of linking them to one another and to the other countries as well as the frequent climatic hazards that often occur there. While the size of land area and resource endowments, population size, GDP (PPP), and per capita income were considered, relatively large middleincome countries were also included in the sample.

3 For uniformity or ease of comparison purposes, all the data used in this chapter were obtained from the World Bank, World Development Indicators.

1 Other early theories of growth and development least relevant to this work have been excluded from the analysis.

2 Nurse's arguments are reproduced in Meier 1964, 358-63.

3 Nelson indicates that while he was working on his theory, Libenstein's book on "The theory of critical minimum effort," was published. Footnote 1, American Economic Review. 1956: 894.

4 Although Myrdal's theory of cumulative causation has been used to explain the persistence of differential geographical development within regions of a country and between countries, we will limit it here, as much as possible, to explain the international aspect of dualism only.

5 The Website of the United Nations Economic Commission for Africa discusses many of the issues concerning capital outflow from Africa as well as brain drain. See uneca.org. Also see Ibi Ajayi and Leonce Ndikumana 2015.

1 The date for this valuation is not always given. The value of these resources should be rising over time as they appreciate or as the value of the dollar changes over time.

2 The neighbors of the DRC are Angola, Burundi, Central African Republic (CAR), Congo Republic, Rwanda, South Sudan, Tanzania, Uganda, and Zambia.

3 Ending the war in the DRC was accomplished through four incremental peace agreements: the Lusaka Ceasefire Agreement (1999), the Sun City Agreement (April 2002), the Pretoria Agreement (July 2002), and the Luanda Agreement (September 2002) that ultimately contributed to the Global and Inclusive Agreement of December 2002 which finally ended the war. Even though these agreements did not effectively curb violence in many parts of the DRC, they served as instrumental pillars for the Global and Inclusive Agreement which led to the formation of a unified Transitional Government of the DRC in 2003. This agreement, however, did not succeed in ridding the DRC of violence, especially in the eastern parts of the country.

4 During the war periods, the informal economy which cuts across all sectors overtook the formal economy. An estimated 80-90 percent of the DRC's population was engaged in the informal sector. In economic value, this parallel economy was estimated to be three times the size of the DRC's formal GDP. In the conflict areas informal war economy took over with militarized natural resources exploitation and trade lying beyond the purview of state administrative institutions.

5 For details, see discussion in this chapter on infrastructure development.

6 In spite of increasing the positive impact of the mining industry on the local population, the mining companies and even the Congolese government are doing the opposite. The Congolese central government refuses or reduces the transfer of the amount of royalty revenues due to the provincial and local governments. The mining companies through 
transfer pricing and other corporate murky ways underestimate or hide their true profits from the tax authorities.

7 Data on DRC trade were not available at the same source as for Ethiopia, Nigeria, and South Africa. Hence, many sources were consulted to piece together the DRC trade data. They included: IMF (2005-2016); World Bank, Development Indicators; UNECA, African Statistical Yearbook, (2005-2016); https://atlas.media.mit.edu/en/profile/ country/cod/ (Accessed February 22, 2017).

8 The central bank (BCC) does not provide figures for industrial diamond production as diamond production is dominated by artisanal and small-scale miners in the DRC, which are together classified as artisanal. Consequently, some diamond production will be considered as artisanal by the BCC, but classified as industrial by the USGS, albeit through numerous, small-scale "industrial" mines. This variation in category definitions explains the large industrial diamond production figures according to the USGS.

9 The existing borders of African countries were drawn up by European governments in their Berlin Conference of 1884/85 when they carved up Africa into their various spheres of influence and colonies.

10 The presence of oil in the region has been known for a long time. Shell explored the Ugandan side of Lake Albert in 1938 and the Congolese side between 1952 and 1954. Interest in the lake only revived with the signature of the first exploration contract in 1997 between the Ugandan Government and Heritage Oil and the arrival of the Tullow Oil Company in 2006 in the DRC.

11 However, they also recognized that the 3 February 1915 agreement between Belgium and the UK was insufficiently precise to determine the border on Lake Albert. Hence, the accords provided for the creation of a joint commission to determine the exact border on the lake, demilitarize the disputed area and establish a joint administration for Rukwanzi Island.

1 World Bank. 2016. An Annual Overview of the Economy of Ethiopia.

2 Data on the plan targets are obtained from the specific documents of each plan, while performance data are obtained in the review parts of succeeding plans. The plan documents are for the SDPRP, PASDEP, GTPI, and GTP II.

3 Kaizen is a Japanese word which translates literally to continuous improvement resulting from every team member in an enterprise making their own small contribution. Late Ethiopian Prime Minister Meles Zenawi introduced it in Ethiopia in 2008 to motivate increase in productivity and product quality by focusing on working behavior, human resources development, and promotion of innovation. The goal is for continuous improvement to lead to big results from many small changes accumulated over time

4 For data on details of Ethiopian trade in 2015, see the same sources as for Nigeria and South Africa: https://globaledge.msu/countries/ethiopia/trade and https://comtrade. un.org/ (Accessed February 19, 2017). Comprehensive trade data for DRC were not available from the same sources.

5 The SNNP stands for Southern Nations, Nationalities, and Peoples': a region bordering Kenya and South Sudan. It is one of the federal regions covering an area of about $112,323 \mathrm{~km}^{2}$ with a population of about 18 million (2018) made up of about 45 ethnolinguistic groups.

6 Most of the data on the performance of the agricultural sector are obtained from the annual reports of the Ethiopian Agency for Agricultural Transformation (EATA), especially the one of 2013/14, which gives an overview of many years. The review parts of the GTPII also give an overview of past performances of agriculture as well as other sectors.

7 CAADP is a pan-African framework that provides a set of principles and broadly defined strategies to help African countries. It champions reform in the agricultural sector, setting broad targets: 6 percent annual growth in agricultural GDP and an allocation of at least 10 percent of public expenditures to the agricultural sector. 
8 Women and youth programs have been explicitly included in Ethiopian development plans, especially in both phases of the GTP.

9 Ethiopia defines its power schemes by size in the following terminologies: large (> $30 \mathrm{MW})$, medium (10-30 MW), small (1-10), mini (501-1,000 kW), micro (11-500 $\mathrm{kW})$, and pico $\leq 10 \mathrm{~kW}$ ) (https://energypedia.info/wiki/Ethiopia_Energy_Situation (Accessed April 18, 2017).

10 The Corbetti geothermal scheme will be the first project to be developed under the US government's Power African Initiative, which was launched 2013 by President Obama in a speech at Cape Town University. This makes $\$ 7$ billion available to support power schemes in Ethiopia, Ghana, Kenya, Liberia, Nigeria, and Tanzania.

11 This project is significant for both Djibouti and Ethiopia as Djibouti's port serves as the gateway for around 98 percent of landlocked Ethiopia's export-import trade, while domestic electricity generation is costly in Djibouti. Producing power with fueloperated generators in Djibouti costs about $\$ 0.25$ per kilowatt hour compared with around $\$ 0.07$ per kilowatt hour of power imported from Ethiopia.

1 In addition to Nigeria, other African countries rebased their economies as follows: Kenya (2013), Tanzania (2013), Uganda (2014), and Zambia (2010).

2 Yemi Kale was the Statistician General (professional head) of the Nigerian National Bureau of Statistics at the time of rebasing the Nigerian national income in 2013. Also see National Bureau of Statistics (April 2014).

3 The details of Nigeria's 2015 trade data were obtained from the same sources for Ethiopia and South Africa: https://globaledge.msu/countries/ethiopia/trade and https:// comtrade.un.org/ (Accessed February 19, 2017). Comprehensive trade data for DRC were not available from the same sources.

4 Courteville Business Solutions was a private firm that provided motor vehicle registry services in twenty of thirty-six Nigerian states.

5 www.vanguardngr.com/2016/03/innoson-signs-pact-air-force-produce-jet-fightersparts/ (Accessed October 20, 2017).

6 See www.vanguardngr.com/2016/03/innoson-signs-pact-air-force-produce-jet-fightersparts/ (Accessed October 20, 2017).

7 See Chapter 7 on South Africa's Motor Industry Development Program (MIDP).

8 The Ajaokuta Iron and Steel industry is one of the most studied industries in writings on Nigerian industrialization.

9 Most of the data on iron and steel are mostly based on the works of Agbu (2007); Lawal (2015); and Nigerian Metallurgical Society (NMS) (2016).

10 www.vanguardngr.com/2014/10/problems-crippling-manufacturing-nigeriaibikunle-ipwa-plc-md/; https://punchng.com/manufacturers-keen-to-tap-idle-elec tricity-as-generation-wobbles/; https://guardian.ng/business-services/industry/manu facturers-generate-13000 mw-from-alternative-energy-sources/ (Accessed October 20, 2017).

11 The Nigerian Bank of Industry (BOI) targets businesses that engage in manufacturing and processing activities. It only finances enterprises or companies and not an individual person or group of persons. It was principally set up to finance industrial equipment used in manufacturing. The bank does not disburse the loan to the borrower in cash but to the vendors and suppliers of the equipment for which the loan application is made.

12 Most of the figures on agricultural performance, quoted below, are available in Adesina's presentation. Also see The Economist, May 4, 2013.

13 Halal is the Muslim view on animals slaughtered in an Islamic way.

1 Although other sources give more details on the sectors represented in Table 6.2, most of the details on the various sectors are contained in: www.southafrica.inf/business/ economy/sectors/manufacturing.htm (Accessed May 20, 2016).

2 Statistics South Africa, South Africa's Economy: Key Sectors. Also see reports of the Financial Services Board and the South African Reserve Bank (various years). 
3 www.southafrica.inf/business/economy/sectors/manufacturing.htm (Accessed May 20, 2016).

4 The South African Electrotechnical Export Council (SAEEC) is a non-profit company established as a Public-Private Partnership between South African business and the Department of Trade and Industry to facilitate the export growth and internationalization of its members in the fields of Electrical Engineering, Electronics, Information Technology, and Telecommunications.

5 The details of South Africa's 2015 trade data were obtained from the same sources for Ethiopia and Nigeria: https://globaledge.msu/countries/ethiopia/trade and https:// comtrade.un.org/ (Accessed February 19, 2017). Comprehensive trade data for DRC were not available from the same sources.

$6 \mathrm{KPMG}$ is an international investment and consulting company with offices in many countries all over the world. In South Africa, it has offices in several cities, including Cape Town, Durban, Johannesburg, and Pretoria.

7 South Africa is in the Southern hemisphere, so the seasons alternate with those of its European major farm products exports.

8 Original equipment manufacturers are foreign car companies from which South Africa companies have imported technology.

9 See www.southafrica.inf/business/economy/sectors/manufacturing.htm (Accessed May 20, 2016).

10 The main manufacturing subsectors in South Africa. Available: www.southafrica.inf/ business/economy/sectors/manufacturing.htm (Accessed May 20,2016).

11 See previous section on communications and ICT.

12 See Chapter 4 on details of South Africa's involvement on the Inga III project in the DRC.

13 Although many articles have been written on this emotional issue, Edward Lahiff has been the major contributor on it.

14 For example, when in February 2017, Julius Mulema, leader of the Economic Freedom Fighters Party (EFF), proposed a motion that would have amended section 25 of the Constitution of South Africa to allow for expropriation of land without compensation, it was resoundingly defeated, 261 to 33 votes. However, a year later, and with a new South Africa president, Cyril Ramaphosa, the call for expropriation without compensation had gained steam. With some amendments proposed by the African National Congress (ANC), the motion was approved by a wide margin. The stage was set for allowing the South African government to take land without compensation and reallocating it as they see fit.

1 The New Partnership for Africa's Development (NEPAD) was established in 2001 by the Organization for African Unity (OAU), the precursor of the African Union (AU), as the socio-economic body charged with accelerating economic cooperation and integration among African countries. The NEPAD Planning and Coordinating Agency (NPCA) is NEPAD's implementing secretariat, which works together with the African Union Commission (AUC) as planners and coordinators of the African Economic Transformation Agenda of the African Union.

2 In 1971, the United Nations Economic Commission for Africa (UNECA) drew a plan for Trans-African Highways (TAH). These included the Cairo-Dakar Highway, DakarNdjamena Highway, Ndjamena-Djibouti Highway, Dakar-Lagos Highway, Lagos-Mombasa Highway, Beira-Lobito Highway, Algiers-Lagos Highway, Tripoli-Windhoek-(Cape Town) Highway, and the Cairo-Gaborone (Pretoria-Cape Town) Highway. For details, see the African Development Bank (AfDB) and the UNECA (2003).

3 For details on the Abuja Treaty, see Chapter 1.

4 The Community of Central African States (ECCAS), the East African Community (EAC), the Southern African Development Community (SADC), and the Economic 
Community of West African States (ECOWAS) have drawn up Infrastructure Master Plans.

5 The discussion in relation to the strategy of regional development poles is limited to PIDA's transport, energy, and ICT programs only as they would impact on most African countries, unlike the trans-boundary water programs whose impacts will be limited to the countries within the specific river basins.

6 In addition to SOFRECO, also see www.au-pida.org. This website and PIDA's annual progress reports contain both historical and current data on PIDA projections and implementation.

7 Refer to note 6 above.

8 For various details on the PIDA programs, see PIDA Progress Reports 2015-2017. The Yamoussoukro Decision of 1999 was made by African Ministers of Transport to open their airspaces to African airlines so as to develop an intra-African air traffic network.

9 Africa's Agenda 2063 is a perspective plan of fifty years from 2013, in which Africa will be transformed into a modern prosperous continent based on regional and continental integration. For details, see African Union Commission. 2015. Agenda 2063: The Africa We Want. Addis Ababa: AUC.

10 The ACEIR was conceptualized as an inter-disciplinary regional infrastructure development and management-focused center of excellence. It comprises regulatory practitioners, professors, and researchers from global universities and research institutes with PIDA staff members driving and coordinating the work programs.

11 The Belt and Road consist of the historical overland Road from China to Europe (the Belt), and a new maritime "Road" that links China to the countries of Southeast Asia, the Gulf countries, East and North Africa, and on to Europe (the Road). In 2013, China proposed the Belt and Road Initiative (BRI) to improve connectivity and cooperation on a transcontinental scale. The scope of the initiative extends worldwide. It is not limited to the countries along the overland and maritime routes only. The BRI is also referred to as the One Belt One Road Initiative.

12 The various projects discussed below are listed more than once in the online sources on the BRI listed in the bibliography.

13 Although China finances its African projects at African national level, the infrastructural projects are either national portions of PIDA projects or complement PIDA's projects. Both types of projects boost Africa's infrastructure and its connectivity.

Chenery, Hollis. 1979. Structural Change and Development Policy. New York, NY: Oxford University Press.

Chenery, Hollis and Moshe Syrquin. 1975. Patterns of Development 1950-1970. Oxford: Oxford University Press.

Cornwall, John. 1977. Modern Capitalism: Its Growth and Transformation. London: Martin Robertson.

Cypher, James M. and James L. Dietz. 2009. The Process of Economic Development. New York, NY: Routledge; Taylor \& Francis Group.

de Vries, Gaaitzen J., Marcel P.Timmer, and Klass de Vries. 2014. "Structural Transformation in Africa: Static Gains, Dynamic Losses." Journal of Development Studies 51, no. 6: 674-88.

Hirschman, Albert A. 1958. Strategy of Economic Development. New Haven, CT:Yale University Press.

Lewis, Arthur W. 1955. The Theory of Economic Growth. London: Allen and Unwin.

. 1954. "Economic Development with Unlimited Supplies of Labor." Manchester School of Economics and Social Studies 22: 139-91.

McMillan, Margaret S., Dani Rodrik, and Inigo Verduzco-Gallo. 2014. "Globalization, Structural Change, and Productivity Growth, With Update on Africa." World Development 63: $11-32$. 
Page, John and Finn Tarp. 2017. The Practice of Industrial Policy: Government-Business Coordination in Africa and East Asia. Oxford: Oxford University Press.

Syrquin, Moshe. 1989. "Patterns of Structural Change." In Handbook of Development Economics, Vol. 2, eds. Hollis Chenery and T. N. Srinivasan. Amsterdam: North Holland Publishers: 203-73.

Timmer, Peter C. 1989. “The Agricultural Transformation.” In Handbook of Development Economics, Vol. I, eds. Hollis Chenery and T. N. Srinivasan. Amsterdam: North Holland Publishers: $276-331$.

Todaro, Michael P. and Stephen C. Smith. 2015. Economic Development. New York, NY: Pearson Addison Wesley.

United Nations Economic Commission for Africa (UNECA). 2015a. Economic Report of Africa Industrializing Through Trade. Addis Ababa: UNECA.

-2015b. Minerals and Africa's Development:The International Study Group Report on Africa's Mineral Regimes. Addis Ababa: UNECA.

United Nations Economic Commission for Africa (UNECA) and African Union Commission (AUC). 2013a. Making the Most of Africa's Commodities: Industrializing for Growth, Jobs and Economic Transformation. Addis Ababa: UNECA.

- 2013b. Policy Brief No 3: Urbanization and Development Transformation in Africa. Addis Ababa: UNECA.

-2011a. Economic Report on Africa 2011: Governing Development in Africa-The Role of the State in Economic Transformation. Addis Ababa: UNECA.

- 2011b. Africa Youth Report 2011:Addressing the Youth Education and Employment Nexus in the New Global Economy. Addis Ababa: UNECA.

-2011c. Policy Brief No 6: Unleashing Africa's Potential as a Pole of Global Growth. Addis Ababa: UNECA.

Weil, N. David. 2009. Economic Growth. New York, NY: Pearson Addison Wesley.

Woldemichael, Andinet, Adeleke Salami, Adamon Mukasa, Anthony Simpasa, and Abebe Shambles. 2017. Transforming Africa's Agriculture Through Agro-Industrialization. Abidjan: AfDB.

World Bank.Various years. World Development Indicators. Washington, DC: World Bank.

Ajayi, Ibi and Leonce Ndikumana, eds. 2015. Capital Flights from Africa: Causes, Effects and Policy Issues. Oxford: Oxford University Press.

Carbaugh, Robert J. 2015. International Economics. Boston, MA: Cengage Learning.

Chenery, Hollis and T. N. Srinivasan, eds. 1988. Handbook of Development Economics, Vol. 1 \& 2. Amsterdam; New York, NY: North-Holland.

Hirschman, Albert O. 1958. Strategy of Economic Development. New Haven, CT:Yale University Press.

International Labor Organization (ILO). 1972. Employment, Income and Equity: A Strategy for Increasing Productive Employment in Kenya. Geneva: ILO.

Klugman, Jeni. 2002. A Sourcebook for Poverty Reduction Strategy Vol. 1: Core Techniques and Cross-Cutting Issues. Washington, DC: World Bank.

Leibenstein, Harvey. 1957. Economic Backwardness and Economic Growth. New York, NY: John Wiley \& Sons: 98.

Meier, Gerald M., ed. 1964. Leading Issues in Development Economics. New York, NY: Oxford University Press.

Meier, Gerald M. and Joseph E. Stiglitz, eds. 2001. Frontiers of Development Economics: The Future in Perspective. New York, NY: World Bank; Oxford University Press.

Myrdal, Gunnar. 1957. Economic Theory and Underdeveloped Regions. London: Duckworth. 
Nelson, Richard R. 1956. "A Theory of the Low-Level Equilibrium Trap in Underdeveloped Economies." American Economic Review 46, no. 1 (December): 894-908.

Nurkse, Ragnar. 1953. Problems of Capital Formation in Underdeveloped Countries. New York, NY: Oxford University Press.

Rosenstein-Rodan, Paul N. 1943. "Problems of Industrialization of Eastern and SouthEastern Europe.” Economic Journal 53, no. 2 (June-September): 202-11.

Salvatore, Dominick. 2013. International Economics. New York, NY: John Wiley \& Sons.

United Nations Development Program (UNDP). 1990. Human Development Report.

Wilber, Charles K., ed. 1973. The Political Economy of Development and Underdevelopment. New York, NY: Random House.

World Bank. 1984. Toward Sustained Development: A Joint Program of Action for Sub-Saharan Africa. Washington, DC: World Bank.

-1981. Accelerated Development in Sub-Saharan Africa:An Agenda for Action. Washington, DC: World Bank.

www.un.org/sustainabledevelopment/sustainable-development-goals/

www.undp.org/content/en/home/sdgoverview/mdg-goals.html

African Development Bank (AfDB). 2013. Democratic Republic of Congo: 2013-2017 Country Strategy Paper (Translated from French). Abidjan: AfDB.

- 2012. Democratic Republic of Congo. www.africaneconomicoutlook.org (Accessed October 8, 2016).

Bikalemesa, Muhaise. 2014. "Investment Opportunities in Democratic Republic of Congo." January 27. http://afkinsider.com/103587/drc-is-the-largest-market-in-subsaharan-africa-for-south-african-products/\#sthash.iIzsJg7J.dpuf (Accessed October 8, 2016).

The Carter Center. 2017. Improving Governance of Revenues from the Mining Industry: CrossCutting Lessons from Fiscal and Para-Fiscal Analyses of Five Mining Projects in the D.R. Congo. Kinshasa: Ministry of Planning, February.

Davis, J. Martyn. 2008. "China and the Democratic Republic of Congo: Partners in Development?” The China Monitor, no. 34 (October).

De Koning, Ruben. 2009. Artisanal Mining and Post Conflict Reconstruction in the Democratic Republic of Congo. Stockholm: International Peace Research Institute (SIPRI), October.

Delvaux, Damien and Max Fernandez-Alonso. 2015. "Petroleum Potential of the Congo Basin." In Geology and Resource Potential of the Congo Basin, eds. Maraten J. de Wit, Francois Guillocheau and Miciel C. J. de Wit. Brussels: Royal Museum for Central Africa: 371-91.

Democratic Republic of the Congo. 2016. The Mining Law Review-Edition 5 Mining: Democratic Republic of the Congo, December.

2015. REDD+ Investment Plan (2015-2020).

-2011a. Growth and Poverty Reduction Strategy Document: Priority Action Plan. Kinshasa: Ministry of Planning.

- 2011b. Growth and Poverty Reduction Strategy Paper [GPRSP 2]. Kinshasa: Ministry of Planning, October.

- 2011c. Growth and Poverty Reduction Strategy Document. Kinshasa: Ministry of Planning. www.imf.org/external/pubs/ft/scr/2013/cr13226.pdf (Accessed October 8, 2017).

-2003. Law No. 007/2002 of July 11, 2002 Relating to the Mining Code Decree No 038 / 2003 of 26 March; Mining Regulation.

European Forest Institute. 2015. REDD+ Investment Plan (2015-2020). Barcelona, Joensuu, and Kuala Lumpur: EUREDD Facility. 
Fall, Latsoucabe. 2010. "Harnessing the Hydropower Potential in Africa: What Should Be the Place and Role of Grand Inga Hydropower Project?" XXIst World Congress, Montreal, Canada, September 12-16.

Herdeschee, Johannes, Kai-Alexander Kaiser, and Daniel Mukoko Samba. 2012. Resilience of an African Giant: Boosting Growth and Development in the Democratic Republic of Congo. Washington, DC: World Bank.

International Crisis Group (ICG). 2012. "Black Gold in the Congo: Threat to Stability or Development Opportunity?” Crisis Group Africa Report No188 (Translation from French). Kinshasa; Nairobi; Brussels, July 11.

International Monetary Fund (IMF). 2015. "Democratic Republic of the Congo: Selected Issues." IMF Country Report No. 15/281, October.

- 2014. "Financial Sector Stability Report, Democratic Republic of the Congo." IMF Country Report No. 14/315.

- 2010. Democratic Republic of the Congo: Enhanced Initiative for Heavily Indebted Poor Countries-Completion Point Document and Multilateral Debt Relief Initiative Paper.Washington, DC: IMF.

- 2007. Democratic Republic of the Congo: Poverty Reduction and Growth Strategy Paper. Washington, DC: International Monetary Fund. www.imf.org/external/pubs/ft/ scr/2007/cr07330.pdf (Accessed October 9, 2017).

-2005-2016. Direction of Trade Statistics Yearbook. Washington, D.C.: IMF.

Kabemba, Claude. 2016. "China-Democratic Republic of Congo Relations: From a Beneficial to a Developmental Cooperation." African Studies Quarterly 16, nos. 3-4 (December). www.africa.ufl.edu/asq/v16/v16i3-4a6.pdf (Accessed April 8, 2018).

Pact. 2010. Promise Study: Artisanal Mining in the Democratic Republic of Congo, June.

Tegenfeld, Mark and Michael Trueblood. 2012. The Democratic Republic of Congo: An Economic Growth Diagnostic Study. Kinshasa: USAID.

United Nations Environment Program (UNEP). 2011. The Democratic Republic of the Congo: Post-Conflict Environmental Assessment; Synthesis for Policy Maker. Nairobi: UNEP.

United States Agency for International Development (USAID). 2014. Country Development Cooperation Strategy: Democratic Republic of the Congo 2014-2019. Washington, D.C.: USAID.

- 2011. Central Africa Regional Program for the Environment (CARPE): Regional Development Cooperation Strategy 2012-2020. http://pdf.usaid.gov/pdf_docs/PDACT704.pdf (Accessed October 22, 2017).

US Geological Survey (USGS). 2013. Mineral Commodity Summaries. Washington, DC: U. S. Department of Interior.

World Bank. 2013. Country Assistance Strategy for the Democratic Republic of Congo for the Period FY2013-FY 2016. Washington, D. C.: World Bank.

World Wide Fund for Nature and World Bank Global Alliance. 2007. Forests in Post-Conflict Democratic Republic of Congo: Analysis of a Priority Agenda. Jakarta, Indonesia: Center for International Forest Research.

World Trade Organization (WTO). 2010. Trade Policy Review: Democratic Republic of Congo. October. Geneva:WTO.

African Development Bank (AfDB). 2013. Federal Democratic Republic of Ethiopia Country Strategy Paper 2016-2020. Abidjan: AfDB.

- 2011. Federal Democratic Republic of Ethiopia Country Strategy 2011-201. Abidjan: AfDB, April.

Altenburg,Tilman. 2010. “Industrial Policy in Ethiopia.” Discussion Paper, Deutsches Institut für Entwicklungspolitik. 
Berhan, Tewolde and Gebre Egziabher. 2017. Renewable Energy Projects in Ethiopia. Addis Ababa. https://unfccc.int/files/bodies/awg/application/pdf/3_ethiopia.pdf (Accessed October 20,2017).

Central Statistics Agency of Ethiopia (CSA). 2010-2011. Report on Small Scale Manufacturing Industries Survey. Addis Ababa: CSA.

-2012. Report on Large and Medium Manufacturing and Electricity Industries Survey. Addis Ababa: CSA.

-2003. Report on Cottage/Handicraft Manufacturing Industries Survey. Addis Ababa: CSA.

Diao, Xinshen. 2010. Economic Importance of Agriculture for Sustainable Development and Poverty Reduction: The Case Study of Ethiopia. Paris: OECD.

Dinh, Hinh,Vincent Palmade,Vandana Chandra, and Frances Cossar. 2012. Light Manufacturing in Africa: Targeted Policies to Enhance Private Investment and Create Jobs: Vol. I. Washington, DC: World Bank.

Ethiopian Agricultural Transformation Agency. (ATA) 2014. 2013/14 and 2014: Transforming Agriculture in Ethiopia. Addis Ababa:ATA.

Gebreeyesus, Mulu. 2013. "Industrial Policy and Development in Ethiopia: Evolution and Present Experimentation.” WIDER Working Paper No. 2013/125.

Gebremeden, Yared. 2016. "Ethiopia: Energy Development to Ensure the Growing Economy." The Ethiopian Herald, March 3.

Girma, Zelalem. 2018. “Ethiopia: Industrial Parks Transforming Manufacturing Sector.” The Ethiopian Herald, Addis Ababa, March 6.

- 2016. "Ethiopia: Industrial Parks Fostering Sustainable Growth." The Ethiopian Herald, June 16.

Haile, Tewelde G. 2015. "Comparative Analysis for the SDPRP, PASDEP, and GTR of the FDR of Ethiopia." Global Journal of Business, Economics, and Management 5, no. 1:13-14.

International Monetary Fund (IMF). 2017. World Economic Outlook, October.

- 2011a. The Federal Democratic Republic of Ethiopia: Joint Staff Advisory Note on Growth and Transformation Plan 2010/11-2014/15.

- 2011b. IMF Country Report: The Federal Democratic Republic of Ethiopia: Poverty Reduction Strategy Paper: Growth and Transformation Plan 2010/11-2014/15:Vol. I.

- 2006. IMF Country Report No. 6/27: The Federal Democratic Republic of Ethiopia: Poverty Reduction Strategy Paper-2003/04 Annual Progress Report. Industrial Parks Development Corporation: www.ipdc.gov.et/index.php/en/ (Accessed August 20,2017).

Kassahun, Chanie. 2018. "Ethiopia: Expanding Industrial Parks to Ensure Sustainable Growth.” Ethiopian Herald, January 10.

Ministry of Finance and Economic Development (MOFED). 2010a. The Federal Democratic Republic of Ethiopia: Poverty Reduction Strategy Paper: Growth and Transformation Plan 2010/11-2014/15: Vol. I: Main Report. Addis Ababa.

-2010b. Growth and Transformation Plan (GTP), 2010/11-2014/15 Draft. Addis Ababa, September.

-2010c. Performance Evaluation of the First Five Years Development Plan (2006-2010) and the Growth and Transformation Planning (GTP) for the Next Five Years (2011-2015). Addis Ababa, July.

- 2006. Plan for Accelerated and Sustained Development to End Poverty (PASDEP), (2005/06-2009/10). Addis Ababa, September.

- 2005. Ethiopia: Sustainable Development and Poverty Reduction Program (SDPRP): Annual Progress Report (2003/04).

. 2002. Ethiopia: Sustainable Development and Poverty Reduction Program (SDPRP). Addis Ababa, July. 
Ministry of Industry. 2002. Industrial Development Strategy of Ethiopia. Addis Ababa, August.

Ministry of Water, Irrigation, and Electricity. 2007. The Ethiopian Power Sector: A Renewable Future. Berlin Energy Transition Dialogue, March.

National Planning Commission. 2016. Growth and Transformation Plan II (GTP II) (2015/162019/20): Vol. I: Main Text. Addis Ababa, May.

Tekle, Tesfa-Alem. 2017. "Ethiopia Pushes Plan to Become Africa's Manufacturing Hub." Sudan Tribune, June 20.

United Nations Industrial Development Organization (UNIDO). (n.d.). Programme for Country Partnership: Ethiopia, Summary.

Woldegebriel, E. G. 2013. "Ethiopia Plans to Power East Africa with Hydro." AlertNet:Thomson Reuters Foundation. Addis Ababa, January 29.

World Bank. 2017. Global Economic Prospects: A Fragile Recovery, June.

Worldbank.org/en/country/ethiopia/overview/ (Accessed October 22, 2016).

Zerihun, A. 2008. "Industrialization Policy and Industrial Development Strategy in Ethiopia." In Digest of Ethiopia's National Policies, Strategies and Programs, ed.T. Assefa. Addis Ababa: Forum for Social Studies: 239-81.

Adeniyi, R. 2015. "ECOWAS CET: FG Smuggles 70\% Duty, Tax on Used, New Vehicles." National Daily (online), April 27. www.nationaldailyng.com/business/maritime/3736(Accessed March 8, 2016).

African Development Bank (AfDB). 2015. Economic Report on Nigeria: 2015 Special Edition. AfDB.

Agbu, Osita. 2007. The Iron and Steel Industry and Nigeria's Industrialization: Exploring Cooperation With Japan Institute of Developing Economies. Osaka: Institute of Developing Economies. Japan External Trade Organization, March.

Akinwumi, Adesina. 2013. "Transforming Nigeria's Agriculture." Speech delivered by Minister of Agriculture and Rural Development Federal Republic of Nigeria, at the Inauguration of the Agriculture and Food Security Center of the Earth Institute of Columbia University, New York, USA, September 10.

Chete, L. N., J. O. Adeoti, F. M. Adeyinka, and O. Ogundele. 2014. Industrial Development and Growth in Nigeria: Lessons and Challenges. The Brookings Institution, African Development Bank, World Institute for Development.

Furlonger, D. 2014. "Nigeria Joins Race to Expand Motor Industry." Business Day Live, October 27. www.bdlive.co.za/africa/africanbusiness/2014/10/27/nigeria-joinsrace-toexpand- motor-industry (Accessed May 10, 2015).

Kale, Yemi. 2015. Reviewing the Structure and Capacity of the Nigerian Economy for Improving Government Revenue. Abuja: National Bureau of Statistics.

KPMG. 2012. Cutting Through Complexity, Nigerian Mining Sector. Manufacturing in Africa. February, 2015.

Lawal, Ganiyu Ishola. 2015. Nigeria's Quest for Industrial Development:The Iron and Steel Quagmire. Lagos: University of Lagos Press.

Manufacturers Association of Nigeria. 2014. Speech by Tella Sulaiman Ibikunle, Chairman of Paints Manufacturers of Nigeria and Managing Director of Manufacturers of Industrial Coatings, Marine, and Building Paints. Quoted in www.vanguardngr.com/2014/10/problemscrippling-manufacturing-nigeria-ibikunle-ipwa-plc-md/ (Accessed October 20, 2017).

Mike, A. Jide. 2010. “The Structure of the Manufacturing Industry.” Paper presented at the National Workshop on Strengthening Innovations \& Capacity Building in the Nigerian Manufacturing Sector. (Ikeja, Lagos). (Mike was then the Secretary General of the Manufacturers Association of Nigeria). 
National Bureau of Statistics (NBS). 2014a. Nigerian Manufacturing Sector: Summary Report: 2010-2012. Abuja: National Bureau of Statistics, October.

- 2014b. Rebasing of National Accounts Statistics: Methodology Notes on Gross Domestic Product (GDP) Rebasing Exercise. Abuja: National Bureau of Statistics, April.

National Planning Commission (NPC). 2009. Nigeria Vision 20:2020: Economic Transformation Blueprint. Abuja: National Planning Commission.

- 2007. Nigeria: National Economic Empowerment Development Strategy (NEEDS2). Abuja: National Planning Commission.

- 2004. Nigeria: National Economic Empowerment and Development Strategy. Abuja: National Planning Commission.

Nigeria Export Processing Zones Authority (NEPZA). 2013. www.nepza.gov.ng (Accessed October 20, 2017).

Nigerian Metallurgical Society (NMS). 2016. Book of Proceedings 32nd Conference and Annual Meeting: 26th-29th October. Kaduna.

Sy, Amadou. 2015. Are African Countries Rebasing GDP in 2014 Findings Evidence of Structural Transformation? Brookings, March 3.

Ugbam, Ogechukwu C. and Ephraim A. Okoro. 2017. "A Strategic Study of the Nigerian Pharmaceutical Sector: Organizational Leadership, Market-share, and Competitive Performance." International Journal of Business, Humanities and Technology 7, no. 1 (March).

United Nations Industrialization Organization (UNIDO). 2011. Pharmaceutical Sector Profile: Nigeria.Vienna: UNIDO.

World Bank. 2017. Nigeria Economic Update: Beyond Oil, Key Drivers for Sustainable Growth, May.

. 2012. World Development Indicators. Washington, DC: World Bank.

United Nations, Department of Economic and Social Affairs, Population Division.

Automotive Industry Export Council (AIEC). 2015. South Africa: Automotive Export Manual 2015. Arcadia: AIEC.

Barnes, Justin and Anthony Black. 2013. "The Motor Industry Development Programme 1995-2012: What Have We Learned?” International Conference on Manufacturing-led Growth for Employment and Equality, Johannesburg, May.

Bhorat, H., A. Hirsch, R. Kanbur, and M. Ncube, eds. 2014. The Oxford Companion to the Economics of South Africa. Oxford: Oxford University Press.

Black, Anthony. 2001. "Globalization and Restructuring in the South African Automotive Industry." Journal of International Development 13, no. 6: 779-96.

Black, Anthony and Sipho Bhanisi. 2006. "Globalization, Imports and Local Content in the South African Automotive Industry." The Birchwood Hotel and Conference Center, Johannesburg, October 18-20.

Farole,T.,T. Naughtin, and N. Rankin. 2014. "South Africa’s Super-Exporters.” ManufacturingLed Growth for Employment and Equality International Conference, Johannesburg. www. developmentdialogue.co.za.49.

Fine, B. and B. F. Z. Rustomjee. 1996. The Political Economy of South Africa: From MineralsEnergy Complex to Industrialization. New York, NY: Routledge.

Finn, A., M. Leibbrandt, and M. Oosthuizen. 2014. "Poverty, Inequality, and Prices in PostApartheid South Africa." WIDER Working Papers, No. 127, UNU-WIDER.

Hall, Ruth and Edward Lahiff. 2004. "Budgeting for Land Reform." Policy Brief Debating Land Reform and Rural Development No. 13, August.

Kepe, Thembela and Ben Cousins. 2002. "Radical Land Reform in Key to Sustainable Rural Development in South Africa." Policy Brief Debating Land Reform and Rural Development No. 3, August. 
KPMG. 2013. "The Role of Mining in the South African Economy." www.sablog.kpmg. co.za/2013/12/role-mining-south-african-economy/ (Accessed October 14, 2015).

Lahiff, Edward. 2007. "Willing Buyer, Willing Seller: South Africa's Failed Experiment in Market-Led Agrarian Reform.” Third World Quarterly 28, no. 8 (December). Available PDF.

Lahiff, Edward and Guo Li. 2012. Land Redistribution in South Africa-A Critical Review. Washington, DC: World Bank, May 28.

Minerals Council. Various years. Mining in South Africa: Annual Reports, Fact Sheets, and Facts and Figures.

National Planning Commission. 2012. National Development Plan: Vision for 2030. Pretoria: National Planning Commission.

. 2011. National Development Plan 2030: Executive Summary. Pretoria: National Planning Commission.

National Treasury. 2015. Budget Review 2014 and 2015.

Organization for Economic Cooperation and Development (OECD). 2015. "Barriers to SMEs in South Africa." OECD Economics Department Working Papers. Paris: OECD Publishing.

- 2013. OECD Economic Surveys: South Africa. Paris: OECD Publishing.

2010. OECD Economic Surveys: South Africa. Paris: OECD Publishing.

Reuters. 2015. "South Africa's Zuma Outlines Land Reform Plans." Report on President Juma's Speech to Parliament, February 14.

Statistics South Africa. 2014. Poverty Trends in South Africa-An Examination of Absolute Poverty Between 2006 and 2011.

- 2012. South Africa's Tourism Industry. South African Iron and Steel Institute (various reports)

World Bank. 2018. South Africa: Overview, April 19.

- 2014. "South Africa Economic Update: Fiscal Policy and Redistribution in an Unequal Society." South Africa Economic Update, No. 6. Washington, DC: World Bank.

- 2012. South Africa Economic Update: Focus on Inequality of Opportunities. Washington, DC: World Bank, Reads 18,012.

Yager, Thomas R. 2016. U. S. Geological Survey, 2013 Mineral Yearbook: The Mineral Industry of South Africa, July.

Zalk, Nimrod. 2014. "What Is the Role of Manufacturing in Boosting Economic Growth and Employment in South Africa?" 11 February. www.econ3x3.org/article/whatrole-manufacturing-boosting-economic-growth-and-employment-south-africa (Accessed October 14, 2017).

African Development Bank (AfDB) and United Nations Economic Commission for Africa (UNECA). 2013. Review of the Implementation Status of the Trans African Highways and the Missing Links:Vol. 2: Description of Corridor. Addis Ababa: UNECA.

African Union Commission (AUC). 2015. Agenda 2063: The Africa We Want. Addis Ababa: African Union Commission.

Edinger, Hannah and Jean-Pierre Labuschange. 2019. “China's Role in African Infrastructure and Capital Projects."https:// www.2deloitte.com/us/en/insights/industry/public-sector/ (Accessed July 18, 2019).

Infrastructure Consortium for Africa (ICA). 2013, 2014, 2016, 2017. Annual Report: Infrastructure Financing Trends in Africa. Abidjan: AfDB.

Kambanda Callixte. 2013. Power Trade in Africa and the Role of Power Pools. Abidjan: AfDB.

Leautier, Frannie A., Michael Schaefer, and Wel Shen. 2015. "The Port of Bagamoyo: A Test for China's New Maritime Silk Road in Africa." www.thediplomat.com/2015/12/ 
the-port-of-Bagamoyo-a-test-for-chinas-new-maritime-silk-road-in-africa/ (Accessed July 20, 2019).

NEPAD, AUC, and AfDB. 2015, 2016, 2017. Programme for Infrastructure in Africa: PIDA-PAP Implementation Progress Report, Vol. I. Addis Ababa: and Midrand (South Africa): AUC and NEPAD.

NEPAD, PIDA, UNECA, and Africaninvestor (Ai). 2017. AU-NEPAD Continental Business Network (CBN) 5\% Agenda Report: Mobilizing Domestic Pension and Sovereign Wealth Fund Capital for PIDA and Other African Infrastructure Projects Through Institutional Investor Public Partnerships (IIPPs). Addis Ababa: and Midrand (South Africa): AUC and NEPAD.

Niyimbona, P. 2005. The Challenges of Operationalizing Power Pools in Africa. Addis Ababa: UNECA.

O’Dowd, Emily. 2016. "Special Report: How Five Major African Rail Projects Are Supported by China." https:// www.smartrailworld.com/five-major-african-projectssupported-by-china (Accessed July 12, 2019).

Pheiffer, Evan. 2017. “Top-10: Africa Infrastructure Projects in 2018.” www.thebusinessyear. com/top-10-china-infrastructure-projects-in-africa-2018/focus (Accessed July 14, 2019).

Pieper, Diemar. 2018. "Geopolitical Laboratory: How Djibouti Became China's Gateway to Africa." www.globalsentinelng.com/2018/02/09/djibouti-become-chinas-gatewayafrica/ (Accessed July 14, 2019).

SOFRECO. (n.d.). Study on Programme for Infrastructure Development in Africa:Africa's Infrastructure Outlooks 2040. Midrand (South Africa): NEPAD.

- (n.d.). Study on Programme for Infrastructure Development in Africa (PIDA) Phase III: Energy. Midrand (South Africa): NEPAD.

Sy, Amadou N. R. 2017. Leveraging African Pension Funds for Financing Infrastructure Development. Washington, DC: Brookings Institution.

Tubei, George. 2018. "10 Massive Projects the Chinese Are Funding in Africa- Including Railways and a Brand-New City." www.businessinsider.com.za/here-are-150-millionrand-products-in-africa-funded-bychina-2018-9 (Accessed July 20, 2019).

UECA and AUC. 2012. Financing for Infrastructure Development in Africa (PIDA). Addis Ababa: UNECA.

United Nations Economic Commission for Africa (UNECA). 2002. Decision Relating to the Implementation of the Yamoussoukro Declaration Concerning the Liberalization of Access to Air Transport Markets in Africa. Addis Ababa: UNECA.

- 2000. Report of the First Meeting of the Monitoring Body of the Yamoussoukro Decision. Addis Ababa: UNECA.

-1999. Decision Relating to the Implementation of the Yamoussoukro Declaration Concerning the Liberalization of Access to Air Transport Markets in Africa. Addis Ababa: UNECA.

-1988. Declaration of Yamoussoukro on a New African Air Transport Policy. Addis Ababa: UNECA.

World Bank. 2019. Belt and Road Economics: Opportunities and Risks of Transport Corridors. Washington, DC: World Bank.

Xinhua. 2018. "Belt and Road Initiative Drives Africa's Integration, Economic Growth." www.xinhuanet.com/english/2018-06/29-137287936.htm (Accessed July 24, 2019).

—. 2017. "Backgrounder: Major-Africa Infrastructure Cooperation Projects." www. xihuanet.com/englisg/2017-03/26c_136158456.htm (Accessed July 24, 2019).

—. 2016. "10 Mega Infrastructure Projects in Africa Funded by China." March 22. www.africanglobe.net/business/10-mega-infrastructure-projects-africa-funded-china/ (Accessed July 24, 2019). 